\title{
Pandangan Keagamaan \\ Majelis Ulama Indonesia Kabupaten Bogor Terkait Kewajiban Menjaga Diri, Pelaksanaan Shalat Jumat dan Pengurusan Mayit Dalam Situasi Darurat Penyebaran Covid-19*
}

\author{
Ahmad Mukri Aji ${ }^{1}$ \\ Universitas Islam Negeri Syarif Hidayatullah Jakarta \\ do \\ $\underline{10.15408 / \text { sjsbs.v7i5.15313 }}$
}

\begin{abstract}
The Covid-19 corona virus has spread to the Bogor regency, which is the buffer zone of the capital city of Jakarta. Therefore, the Indonesian Ulema Council of Bogor Regency needs to respond to this emergency situation by providing insights related to the attitude of worship of Muslims, both the obligation to Friday prayers, praying in congregation in the mosque, as well as handling the deadly infected with the corona covid-19 virus. The method of writing this article uses a literary approach, namely from the books of Turats, in addition to referring to the propositions of the Koran and al-Hadith. With the religious views of the Bogor Regency MUI it is expected to be able to provide an overview for the people of Bogor in particular and to the Indonesian public in general in dealing with the Cobid-19 pandemic coronavirus.
\end{abstract}

Keywords: Outlook, Indonesian Ulema Council, Bogor Regency

\begin{abstract}
Abstrak
Penyebaran virus corona Covid-19 telah menyebar ke wilayah Kabupaten Bogor, yang merupakan daerah penyanggah Ibukota Jakarta. Oleh karena, Majelis Ulama Indonesia Kabupaten Bogor perlu menyikapi kondisi darurat ini dengan memberikan pandangan terkait sikap peribadatan umat Islam, baik itu kewajiban shalat jumat, shalat berjamaah di masjid, maupun penanganan mayit terinfeksi virus corona covid-19. Metode penulisan artikel ini dengan menggunakan pendekatan literatur, yaitu dari kitab-kitab turats, selain merujuk kepada dalil al-Quran dan al-Hadits. Dengan adanya pandangan keagamaan dari MUI Kabupaten Bogor ini diharapkan dapat memberikan gambaran bagi masyarakat Bogor khususnya dan pada masyarakat Indonesia secara umum dala menghadapi pandemic coronavirus Cobid-19 ini.
\end{abstract}

Kata Kunci: Pandangan, Majelis Ulama Indonesia, Kabupaten Bogor

*Diterima: 18 Maret 2020, Revisi: 20 Maret 2020, Diterbitkan 14 Mei 2020.

${ }^{1}$ Ahmad Mukri Aji adalah Dosen tetap bidang Hukum Islam pada Fakultas Syariah dan Hukum Universitas Islam Negeri Syarif Hidayatullah Jakarta. E-mail: mukri.aji@uinjkt.ac.id. 


\section{Pendahuluan}

World Health Organization (WHO), organisasi kesehatan dunia sudah lama menetapkan virus Corona Covid-19 sebagai pandemi. Menurut data terakhir, tidak kurang dari 192 negara terkena penyebaran virus ini, tak terkecuali Indonesia. Kini, penyebarannya di Indonesia semakin meningkat tajam, setiap harinya pemerintah mengumumkan jumlah orang positif terjangkit dengan angka kenaikan yang terus naik berlipat. Berbagai upaya sudah dilakukan oleh pemerintah, baik Pusat maupun Daerah demi mengendalikan penyebaran virus mematikan ini, salah satunya dengan menghimbau masyarakat agar mengurangi aktivitas ke luar rumah, tidak menghadiri kegiatan yang melibatkan banyak orang dan keramaian, menghindari tempat-tempat kerumunan, dan lainnya. Sebab, diyakini secara medis bahwa virus Corona dapat menular cepat hanya dengan kontak fisik dengan orang yang terjangkit atau terkena benda yang terkontaminasi virus Corona, sementara untuk mengetahui seseorang terjangkit atau tidak sungguh sangat sulit. Tidak sampai disitu, keterangan dari dunia medis menyebutkan bahwa apabila pasien Covid-19 meninggal, maka virusnya tetap dapat menular kepada orang lain. Artinya, virus di tubuh orang yang sudah meninggal akibat Covid-19 ini tetap hidup dan dapat berpindah melalui kontak fisik atau mengkontaminasi benda yang melekat dengan badan mayit. Konsekuensinya, perlakuan terhadap jenazah pasien Covid-19 memerlukan kehati-hatian tinggi, tidak lain demi menekan penyebaran virus mematikan ini.

Sebagaimana diketahui, penyebaran virus ini sudah sampai ke Kabupaten Bogor, jumlah korban terjangkit pun terus mengalami peningkatan setiap harinya seiring dengan penyebaran di tingkat nasional. Bupati Bogor telah mengkonfirmasi dan bahkan terus melakukan update informasi setiap harinya terkait penyebaran virus ini di Bumi Tegar Beriman. Selain sebagai wilayah dengan tingkat kepadatan penduduk tertinggi dan populasi Muslim terbanyak se Indonesia, Kabupaten Bogor juga secara geografis merupakan wilayah penyangga ibu kota, Jakarta, yang dalam hal penyebaran virus Corona, berdasarkan informasi resmi DKI Jakarta merupakan provinsi dengan tingkat penyebaran tertinggi di Indonesia. Tentu hal ini berimbas cepat kepada Kabupaten Bogor. Bahkan, Gubernur Jawa Barat pada 21 Maret 2020 menetapkan Kabupaten Bogor sebagai Zona Merah penyebaran Covid-19.

Di sisi lain, dalam Islam, terdapat syariat yang meniscayakan keterlibatan orang banyak misalnya shalat berjamaah dan shalat Jum'at di masjid. Jika shalat berjamaah bersifat sunnah muakkadah, maka shalat Jum'at adalah wajib 'aini, wajib bagi setiap laki-laki Muslim yang aqil baligh. Karena itu, jika tidak ada uzur syar'i, maka bisa dipastikan semua laki-laki muslim akan datang melaksanakan shalat Jumat ke masjid.

Dari permasalahan diatas timbul beberapa pertanyaan yang menjadi bahan analisis dalam artikel ini, yaitu; bagaimana hukum melaksanakan ibadah yang meniscayakan keterlibatan banyak orang seperti shalat Jumat dalam kondisi darurat Corona seperti sekarang? Apakah tetap dilaksanakan demi tercapainya Hifzhuddin dengan resiko tertular virus mematikan? Atau shalat jumat tidak diselenggarakan demi menjaga jiwa dari marabahaya (Hifzhunnafs)? 
Selain itu, dalam konteks pasien meninggal akibat Covid-19, dalam Islam juga terdapat syariat yang harus dijalankan oleh Muslim terhadap mayit, yakni mengurus pemulasaraan mayit (Tajhizul Mayyit). Seorang mayit Muslim selain Syahid harus dimandikan, dikafani, dishalatkan dan dikuburkan. Pertanyaan selanjutnya, bagaimana menjalankan pemulasaraan mayit yang terjangkit Covid-19? Sementara dalam dunia medis, hampir bisa dipastikan, meski orang yang terjangkit sudah meninggal, virusnya tetap dapat menular dengan cepat kepada orang lain.

\section{Fatwa MUI Pusat Nomor 14 Tahun 2020}

Dalam situasi demikian, Majelis Ulama Indonesia (MUI) Pusat pada 16 Maret 2020 menerbitkan Fatwa Nomor 14 Tahun 2020 tentang Penyelenggaraan Ibadah dalam Situasi Terjadi Wabah Covid-19, yang termasuk di dalamnya menjawab pertanyaan di atas. Fatwa tersebut harus terus disosialisasikan serta dijadikan pedoman bagi Umat Islam di Indonesia agar pelaksanaan ibadah tetap ada dalam pertanggungjawaban ilmiah. Atas dasar itu, MUI Kabupaten Bogor memandang sangat penting menyampaikan pandangan keagamaan untuk memperkuat Fatwa MUI Pusat, sekaligus untuk menyikapi dinamika Umat Islam di Kabupaten Bogor dalam situasi darurat virus Corona agar dapat dijadikan pertimbangan dan rujukan oleh masyarakat Kabupaten Bogor.

\section{Kewajiban Menjaga Diri dari Covid-19}

Covid-19 merupakan wabah (Tha'un) yang oleh banyak ulama dikategorikan sebagai penyakit atau keadaan yang menakutkan (al-maradh al-makhuf). Analogi hukum Covid-19 kepada Tha'un tentu saja karena banyaknya kesamaan antar keduanya, baik dalam hal penularan, resiko penyakit, maupun jangkauan penularannya.

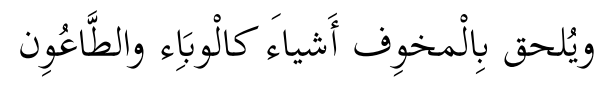

Dan beberapa hal dikategorikan sebagai (penyakit) menakutkan diantaranya seperti Waba' dan Tha'un. ${ }^{2}$

Selain itu, Pandangan ulama di atas juga sejalan dengan kesepakatan lain dari ulama mengenai larangan memasuki kawasan yang terjangkit Tha'un seperti yang disebutkan oleh Imam al-Bujayrami:

$$
\text { ويَرَرُمُ دخوُل بَلَد الطَّاعُون والُْخْوج منها بلا حاجِة لِوجوِد النهي عن ذلك }
$$

Dan haram memasuki wilayah/daerah yang terjangkit Tha'un dan keluar wilayah/daerah tersebut tanpa ada kebutuhan apapun karena adanya larangan dari melakukan hal tersebut. ${ }^{3}$

\footnotetext{
2 Syamsuddin al-Ramli/Imam al-Ramli, Nihayah al-Muhtaj ila Syarh al-Minhaj, juz 19 hlm. 231.

${ }^{3}$ Imam al-Bujayrami, Hasyiyah al-Bujayrami, juz 5 hlm. 17.
} 
Larangan tersebut merupakan hasil dari Ijtihad para ulama memaknai beberapa Hadits Sahih yang menjelaskan larangan memasuki tempat yang terjangkit Tha'un karena dikhawatirkan akan terjangkit. Seperti yang diriwayatkan oleh Imam Bukhari:

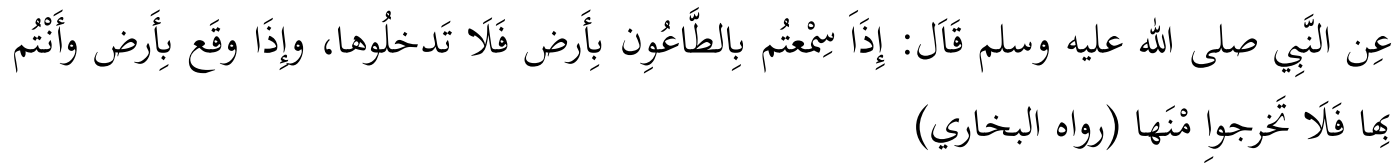

Dari Nabi saw sesungguhnya beliau bersabda: "Jika kamu mendengar wabah di suatu wilayah, maka janganlah kalian memasukinya. Tapi jika terjadi wabah di tempat kamu berada, maka jangan tinggalkan tempat itu." (H.R al-Bukhari)

Dari pandangan ini dapat disimpulkan bahwa menjaga diri dari penularan Covid-19 merupakan kewajiban bagi setiap Muslim. Syariat melarang melakukan perbuatan yang berpotensi meningkatkan penyebaran virus ini dengan cara apapun. Pembangkangan terhadap perintah/larangan ini merupakan sebuah perbuatan yang tidak dibenarkan syariat. لاضرر ولاضرار Tidak boleh membahayakan diri sendiri dan membahayakan orang lain, merupakan salah satu prinsip dalam syariat Islam.

Oleh sebab itu, menghadiri perkumpulan/keramaian atau mendatangi tempat yang "dipastikan" terjangkit Covid-19 merupakan sesuatu yang tidak dibenarkan oleh syariat. Atau sebaliknya, seseorang yang mengetahui/diketahui terjangkit Covid-19 berdasarkan keterangan otoritatif (dunia medis/kedokteran), maka orang tersebut dilarang mengunjungi tempat yang meniscayakan keramaian. Karenanya, keharusan isolasi bagi orang positif Covid-19 itu sudah sesuai dengan syariat.

Apabila kegiatan atau tempat tersebut belum diketahui terjangkit atau tidak, maka kewaspadaan tinggi tetap harus dikedepankan dengan cara-cara yang sudah dianjurkan oleh pemerintah seperti menjaga jarak komunikasi, social distancing, mengenakan masker, menjaga kebersihan tangan, dan lainnya, mengingat betapa sulitanya Covid-19 ini atau bahkan tidak bisa terdeteksi secara kasat mata.

Apalagi diperkuat juga dengan fakta bahwa Kabupaten Bogor sudah ditetapkan sebagai Zona Merah penyebaran Covid-19. Hal ini sesuai dengan dengan kaidah Fiqih: "الَّفْعَ أَقْوى من الَّرفْعَ Menolak/mencegah itu jauh lebih baik dari pada mengangkat/mengobati".

Bagaimana dengan kegiatan peringatan hari besar Islam seperti peringatan Isra Mi'raj dengan model acara Tabligh Akbar yang notabene masih banyak diselenggarakan di wilayah Kabupaten Bogor? Tentu saja ini masuk dalam kategori di atas meskipun atas dalih keagamaan. Sebab yang dilarang bukan Syi'ar Islamnya, namun pada sesuatu faktor eksternal أمر خارجيyang dapat membahayakan orang orang banyak. Dalam hal ini, pemerintah, khususnya Kabupaten Bogor harus ekstra ketat membatasi setiap kegiatan yang meniscayakan kerumunan orang dan melibatkan keramaian, yang memungkinkan terjadinya penyebaran Covid-19, terlebih di wilayah yang kemungkinan, besar kemungkinan, dan yang dipastikan terjangkit. 


\section{Penyelenggaraan Shalat Jum'at dalam Situasi Darurat Covid-19}

Imam Bukhari mengemukakan sebuah Hadits Sahih yang menjelaskan tentang salah satu udzur salat Jum'at:

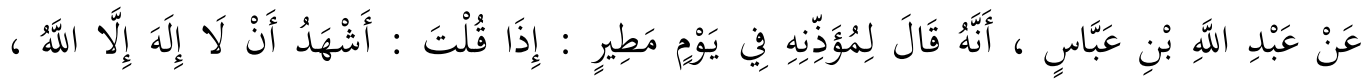

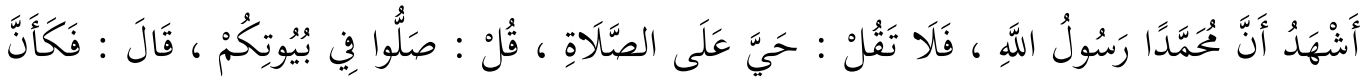

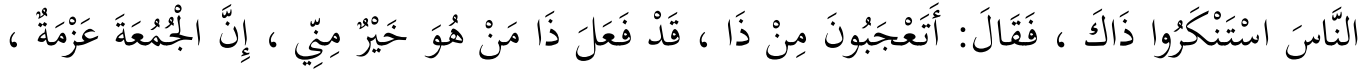

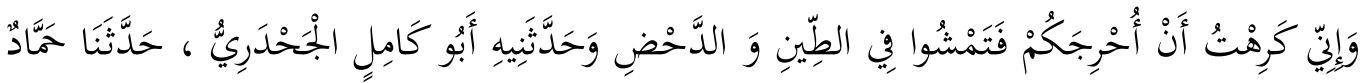

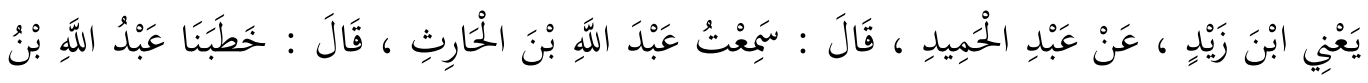

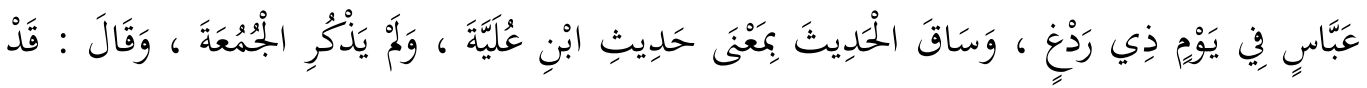

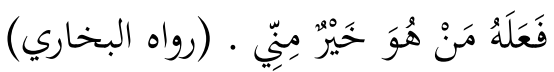

Dari 'Abdullah ibn 'Abbas r.a bahwa sesungguhnya ia berkata kepada Muadzinnya (orang yang mengumandangkan azan) ketika turun hujan (pada siang hari jum'at) "Jika engkau telah mengucapkan "Asyhadu anna Muhammadan Rasulullaah" maka janganlah engkau ucapkan "Hayya 'alash shalaah", namun ucapkanlah "Shalluu fii buyuutikum" (shalatlah kalian di persinggahan kalian). Maka sepertinya orang-orang tidak menyetujui hal ini. 'Abdullah ibn 'Abbas berkata: "Hal demikian ini pernah dilakukan oleh orang yang lebih baik dariku (maksudnya Rasulullah saw), shalat jum'at memang wajib namun aku tidak suka jika harus membuat kalian keluar sehingga kalian berjalan di lumpur dan comberan." (H.R Bukhari dalam Shahih Bukhari, Hadits No. 901).

Hadits tersebut berpesan bahwa Rasulullah saw pun pernah memperingatkan umatnya bahwa ada toleransi untuk merubah, mengganti atau meninggalkan kewajiban apabila kewajiban tersebut harus dilakukan dengan susah payah dan mendatangkan mudharat bagi diri dan orang lain. Menjadi pendapat mayoritas ulama bahwa terdapat beberapa halangan (udzur) bagi seorang Mukallaf untuk tidak melaksanakan salat Jum'at dan Salat Jama'ah. Diantaranya adalah karena ada sesuatu kondisi yang dikhawatirkan akan mengancam jiwa. Seperti apa yang dikemukakan oleh Syaikh Ibrahim al-Bajuri:

$$
\begin{aligned}
& \text { فلاً تجب الجمعة على كافر أصلى وصبي وبجنون ورقيق وأننى ومريض ونحو قولوا ومريض ونحوه من } \\
& \text { كل معذور بمرخص في ترك الجماعة مما يتصور بنا بخلَف مالا يتصور بنا وبو الريح الباردة ليلَ وأما } \\
& \text { ما يتصور بنا فكالحر والبرد والوحل والجوع والعطش والخوف على معصوم من مال أوعرض أو }
\end{aligned}
$$

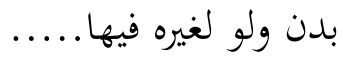

Maka tidak wajib melaksanakan shalat Jum'at bagi Kafir Ashli, anak-anak, orang gila, hamba sahaya, wanita, orang sakit dan sejenis sakit. (orang sakit dan sejenisnya) maksudnya setiap kondisi yang dipandang sebagai alasan boleh meninggalkan shalat berjamaah yang dapat digambarkan di sini -sebagai 
kondisi yang memungkinkan sesorang tidak dapat shalat berjama'ah-. Beda halnya jika kondisi tersebut tidak dapat digambarkan -secara rasional- seperti udara dingin waktu malam. Adapun yang dapat digambarkan di sini -sebagai kondisi yang memungkinkan sesorang tidak dapat shalat berjama'ah- adalah seperti panas, dingin, becek, lapar, haus, dan takut akan -hilangnya- sesuatu yang ma'shum (harus dijaga) baik harta, kehormatan, dan badan (jiwa), meskipun milik orang lain. ${ }^{4}$

Juga yang dikemukakan oleh Syaikh Abdullah ibn Abdurrahman ibn Abu Bakar Bafadhal al-Hadhrami:

$$
\begin{aligned}
& \text { فصل في أعذار الجمعة والجماعة أعذار الجمعة والجماعة المطر إن بل ثوبو ولم يجد كنا والمرض } \\
& \text { الذي يشق كمشقتو وتمريض من لا متعهد لو وإشراف القريب على الموت أو يأنس بو ومثلو } \\
& \text { الزوجة والصهر والمملوك والصديق والأستاذ والمعتق والعتيق ومن الأعذار الخوف على نفس و أو } \\
& \text { عرضوا أو مالوا ... (المقدمة الحضرمية: عبد الله عبد الرحمن بافضل الحضرمي ص:19 }
\end{aligned}
$$

Di antara udzur shalat Jum'at dan shalat berjama'ah adalah hujan yang dapat membasahi pakaiannya dan tidak diketemukan pelindung hujan, sakit yang teramat sangat, mengurus orang sakit yang tidak terdapat yang mengurusinya, mengawasi kerabat (istri, mertua, budak, teman, ustadz, orang yang memerdekannya) yang hendak meninggal atau berputus asa. Termasuk ke dalam udzur Shalat Jum'at dan Jama'ah adalah khawatir akan keselamatan jiwa atau hartanya... ${ }^{5}$

Karena itu, orang yang sudah tahu bahwa dirinya positif mengidap Covid-19 maka virus corona bukan hanya udzur (alasan) yang membolehkan yang bersangkutan meninggalkan shalat Jum'at, melainkan juga menjadi larangan baginya untuk menghadiri salat Jum'at. Dalam konteks ini, pengidap Covid-19 dapat dianalogikan dengan pengidap penyakit lepra (Judzam) dan kusta (Barash) yang dilarang menghadiri salat Jum'at, mereka harus diisolasi dari orang lain.

"Al-Qadli 'Iyadh telah menukil pendapat dari para ulama yang menyatakan bahwa orang yang terkena penyakit lepra dan kusta dilarang ke masjid, shalat jumat, dan berbaur dengan orang lain." 6

Begitu juga apabila umat Islam yang tinggal di wilayah zona merah, yang dipastikan atau besar kemungkinan terjangkit Covid-19, maka umat Islam dianjurkan untuk melaksanakan salat Zhuhur di rumah dan tidak perlu memaksakan untuk menyelenggarakan salat Jum'at di masjid. Sebab di zona ini, potensi penyebaran virus sudah sangat kuat. Maka dalam hal ini, penularan Covid-19 bukan hanya sebagai Udzur, tapi juga larangan dalam menyelenggarakan salat Jum'at.

${ }^{4}$ Hasyiyah alBajuri ‘ala Fathil Qarib Li Ibn Qasim al-Ghazi juz 1 hal 212.

5 Abdullah ibn Abdurrahman ibn Abu Bakar Bafadhal al-Hadhrami, Al-Muqaddimah alHadhrami, hlm. 91.

${ }^{6}$ Zakariya al-Anshari, Asna al-Mathalib Syarhu Raudlath-Thalib, Bairut: Dar al-Kutub al‘Ilmiyyah, juz, I, h. 215. 
Sebagai gantinya, umat Islam tetap diwajibkan melaksanakan salat Dzuhur di rumah masing-masing. Dalam konteks ini berlaku kaidah fiqih; suatu kewajiban tidak bisa ditinggalkan kecuali untuk kewajiban lain, yang dalam hal ini adalah kewajiban menjaga jiwa.

Sementara umat Islam yang mendiami kawasan yang potensi penyebarannya cukup tinggi (zona kuning), penularan Covid-19 dipandang sebagai Udzur dapat meninggalkan salat Jum'at, bukan sebagai larangan. Jika memaksakan salat Jum'at diselenggarakan, kewaspadaan tinggi betul-betul harus tetap dikedepankan. Meski demikian, mengingat betapa berbahayanya Covid-19 ini, umat Islam yang berada di zona kuning pun tetap dianjurkan mengambil rukhshah, yakni tidak melaksanakan salat Jum'at dan menggantinya dengan salat Dzuhur.

Adapun di kawasan yang dipastikan steril dari penyebaran Covid-19 menurut pihak berwenang (zona hijau), salat Jum'at tetap wajib dilaksanakan dengan tetap menerapkan perilaku waspada dan kehati-hatian, karena, sekali lagi, Covid-19 sangat sulit atau bahkan tidak dapat terdeteksi, apalagi dengan kasat mata. Kemungkinan terburuk harus selalu menjadi acuan masyarakat.

\section{Pemulasaraan Mayit yang Terjangkit Covid-19}

Islam mensyariatkan kepada umatnya untuk memuliakan mayit (ihtiramul mayyit) dalam pemulasaraannya (tajhizul mayyit), baik ketika memandikan, mengkafani, mensolatkan dan menguburkan. Kesemuanya harus dilakukan dengan adab dan tata cara yang menjunjung tinggi kemanusiaan. Namun dalam situasi darurat Corona seperti sekarang ini, pemulasaraan jenazah pasien Covid-19 tentu memerlukan perilaku khusus, bukan karena ingin menghinakan mayit, melainkan karena apabila dilakukan dengan tata cara pada umumnya, diduga kuat dapat menimbulkan bahaya bagi yang melaksanakannya, yaitu penularan virus. Sementara, menghindari bahaya دفع المفاسد merupakan salah satu prinsip syariat.

Karena itu, pemulasaraan jenazah pasien Covid-19 memiliki ketentuan:

a. Sebagaimana telah dikemukakan di atas bahwa Covid-19 dikategorikan sebagai Tha'un, maka orang yang meninggal akibat terjangkit Covid-19 kedudukannya adalah Syahid fil Akhirah yang dalam perlakuan kepadanya sama seperti kepada jenazah Muslim pada umumnya; dimandikan, dikafani, dishalatkan dan dikuburkan.

$$
\text { وأما شهيد الأخرة فقط فهو كغير الشهيد فيغسل ويكفن ويصلى عليو ويدفن }
$$

Dan adapun (mayit) syahid akhirat saja, maka (pemulasaraannya) sama seperti mayit bukan syahid, ia dimandikan, dikafani, dishalatkan dan dikuburkan. ${ }^{7}$

\footnotetext{
${ }^{7}$ Hasyiyah al-Bajuri „ala Fathil Qarib Li Ibn Qasim al-Ghazi juz 1 hal 244.
} 
b. Memandikan jenazah pasien Covid-19 harus dengan menggunakan peralatan yang dapat mencegah penularan virus tersebut. Orang yang memandikannya pun harus yang betul-betul terampil dan profesional atau petugas kesehatan serta harus disertai dengan melindungi diri dan memastikan keamanannya seperti mengenakan pakaian khusus pelindung, masker, sarung tangan, desinfeksi diri, dan lainnya. Setelah itu kemudian jenazah dibungkus dengan kain kafan oleh orang yang juga sudah dipastikan keamanannya. Kemudian setelah itu kembali dibungkus dengan sejenis plastik agar tidak mudah tercemar.

c. Apabila menurut ahli memandikan dengan cara seperti di atas dikhawatirkan tetap tertular virus, maka jenazah dapat dimandikan dengan cara menuangkan air ke seluruh badannya tanpa digosok.

$$
\text { واعلم أنّ أقلّ غسل الميّت تعميم بدن و بالماء مّرة واحدة }
$$

Ketahuilah bahwasanya batas minimal memandikan mayit adalah membasahi seluruh badan dengan air satu kali. ${ }^{8}$

Namun apabila dengan cara itu juga masih dikhawatirkan tertular, maka proses memandikan mayit dapat diganti dengan Tayamum;

$$
\text { ومن تعذر غسلو لفقد ماء أو نحوه كاحتراق لو غسل لتهرى يمم }
$$

Dan barang siapa (mayit) yang kesulitan memandikannya karena tidak ada air atau lainnya seperti (mayit) terbakar yang apabila dimandikan akan hancur, maka tayamumilah (mayit tersebut). ${ }^{9}$

Apabila hal itu juga tidak dapat dilakukan karena dalam kondisi darurat, maka jenazah boleh langsung dikafani tanpa dimandikan/ditayamumi. Karena kondisi yang betul-betul darurat menimbulkan kemudahan.

d. Adapun protokol atau teknis mengkafani, memandikan dan menguburkan jenazah pasien Covid-19 yang lebih sempurna secara medis harus mengikuti arahan dari para ahli medis.

\section{Kesimpulan}

Demikian pandangan keagamaan dan himbauan ini disampaikan agar diketahui dan dilaksanakan khususnya oleh umat Islam di Bumi tegar Beriman, semoga kita semua tetap ada dalam lindungan Allah swt dan diselamatkan dari segala marabahaya. Amin.

\footnotetext{
${ }^{8}$ Ibn al-Qasim al-Ghazi, Matn Fathul Qarib alMujib, dalam Hasyiyah al-Bajuri juz 1 hlm. 247.

${ }^{9}$ Syaikh Nawawi al-Bantani, Nihayatuzain, hlm. 151.
} 


\section{Referensi:}

Al-Anshari, Zakariya. Asna al-Mathalib Syarhu Raudlath-Thalib, Bairut: Dar al-Kutub al-'Ilmiyyah, juz, I.

Al-Bajuri Hasyiyah. Ala Fathil Qarib Li Ibn Qasim al-Ghazi juz 1.

Al-Bantani, Syaikh Nawawi. Nihayatuzain.

Al-Bujayrami, Imam. Hasyiyah al-Bujayrami, juz 5.

Al-Ghazi, Ibn al-Qasim. Matn Fathul Qarib alMujib, dalam Hasyiyah al-Bajuri juz $1 .$.

Al-Hadhrami, Abdullah ibn Abdurrahman ibn Abu Bakar Bafadhal. Al-Muqaddimah al-Hadhrami.

Al-Ramli, Syamsuddin.; Imam al-Ramli, Nihayah al-Muhtaj ila Syarh al-Minhaj, juz 19.. 
Ahmad Mukri Aji

494 - Fakultas Syariah dan Hukum UIN Syarif Hidayatullah Jakarta 